\title{
University Education and the Challenges of Development in African Society
}

\author{
Olatunji, Felix $\mathrm{O}^{*}$
}

\section{Abstract}

The importance of education can never be under-played in any society as it is the most potent weapon left to man in order to transform, change and liberate himself and the society from the slavery of ignorance and backwardness. This is done in order to attain rapid development in all ramifications. The epistemic foundation for the establishment of higher institutions (universities) has been devoted to the production of knowledge and cultural reproduction through the ages. It should be known from the outset that universities are moulded on the foundation and systemic structure of the Western ideologies. But there are salient barriers towards the pursuit of higher education in Africa, which are multifaceted and multi-dimensional. The thrust of this paper, then, will be to examine the challenges higher education has in Africa, which hinders its process of producing a body of knowledge that will elevate the human conditions and posit it for all-round development. Therefore, the methodology shall be purely analytic in nature.

* Department of General Studies (Philosophy Unit), Ladoke Akintola University of Technology, P. M. B. 4000, Ogbomoso, Nigeria; felixolatunji28@gmail.com, felixolatunji28@yahoo.co.uk, foolatunji@lautech.edu.ng 


\section{Towards an Understanding of University Education}

Education can be said to be a process of renewal of the meanings of experiences through a process of transmission partly incidental to the ordinary companionship or intercourse of adults and youths; partly deliberately instituted to effect social continuity. This process is seen to involve control and growth of both the immature individual and the group in which (s)he lives. Throughout history as Cajete remarks, human societies have attempted to guide, facilitate, and even coerce the instinct of learning toward socially defined ends. The complex of activities for forming human learning is what we call "education" (1994: 25). The importance of education can never be under-played in any society according to Awolowo, as it is the most potent weapon left to man to transform, change and liberate himself and society from the slavery of ignorance, disease, poverty and backwardness, and attain rapid socio-economic and political progress, prosperity, peace and happiness (Ogunmodede, 1986: 218). It is in fact the only power left in the world that is greater than the forces of nature that man has now enslaved.

The epistemic foundation for the establishment of universities has been devoted to the production of knowledge and cultural reproduction through the ages of man's existence. It has been the main objective of higher education of any nation to do and achieve the above in the best interest of her nationals. It should and ought to be known from the outset that Nigeria's (nay African) universities are an off-shoot of the academies in the ancient period through the monastic system of Christian scholars both in the medieval and modern eras. We should also be clear that universities from this part of the world were and are moulded on the foundation and systemic structure of the western nations, thereby being guided by western forms of educational acquisition and degrees for the emancipation of our cultural background. This would be engineered in order that there will be no definite demarcation and differences from "the gown to the town" as the two must be fused in harmony for the growth, development and reconstruction of human society.

The classical conception of the university is that of a community of scholars searching for and propagating knowledge for its own sake. 
Modern conceptions diverge from this significantly. Jega sees the university as a public service corporation provided by the government while another views it as an enterprise in the knowledge industry, selling whatever mix of academic services it is most profitable to produce to whoever is willing and able to buy them (Egbokhare, 2007: 59). With diverse opinions and views concerning university education, there is the utmost need to reaffirm the bi-roles of university system, namely: that of universal development of human knowledge and that of applying this to the production of culture that will meet with the demands and aspirations of the society.

The essential purpose of the university, therefore, in the words of Owolabi (2007: 71) is to produce a body of knowledge that will elevate the human condition in general and also in particular help the host community to resolve those problems preventing the society from realising its aspirations. This essence is in two forms teaching and research. Though, teaching was the basis in the early days of university but research developed later for the development of man, society and nature. This means that each university community adopts the principle that its academians must not only teach, but also be engaged in serious research, then, communicate the results of their research activities to the outside world (Kenny, 2007: 26).

Another aspect of university education is its universality in personnel and body of knowledge. This is an aspect, which must not be neglected in the process of a university achieving its objectives (its philosophy). What the above represents is that the university must embrace all branches of learning, according to Kenny (2007: 26) - the arts, which is the story of man; the sciences as the story of nature; and religion as the story of God. These areas are significant for the development of its recipients and the society in general; this is the fact that by taking part in these and other fields of learning, they (students) are expected to engage in interdisciplinary dialogue in order to develop a liberal, synthetic and critical mind for themselves and the world around them.

University education would be at its best when there is universality in its personnel - both students and teachers from everywhere without limiting it to a particular clime. This is done to avoid the 
breeding and production of ethnic and racial chauvinists and even to religious bigots as it is the case in many universities. University education ought to be divulged from homogenous society where only particular students and teachers from particular region, religion, race and or ethnic group dominate. Today, universities that lead both in research and in teaching are those that allow and owe their greatness to the latitude and in-take of both the students and teachers, which is reflected in great citadels of learning especially in the Global North.

Apart from morality and character formation that a university education bestows on its recipients, the social role is also significant. Universities are supposed to provide high-level manpower for national development; it exists in a socio-political, historical and cultural milieu because it is a collection of individuals with interpretations of the university mission and philosophy meaning that it has a crucial role to play in the process of social transformation in the society. This process requires restructuring new values, new orders of life and new social structures. This is to say that the university system is central to this process by defining its norms, values, ethos and stages. But if this focus is not attained, then, it brings out a dis-oriented human society as the "Ivory Tower" refuses to abide to its values and objectives.

The system should also be committed to promoting societal and corporate well-being and advancement by refining the ability of its members by enquiring into and seeking to explain the development and functions of man. Rotem and Glasman remark that the outputs of a university are critical factors for the maintenance and adaptive structures of the society because it is an institution, which advances and diffuses consciousness for the entire society (Arikewuyo, 15). This is a clear necessity in the attainment, production and contribution to the society. But this seems to be a utopia among societies in the Global South especially in Africa where education is taken for granted. These problems will be examined in the next section of this paper. 


\section{Challenges of University Education in Africa (Nigeria)}

For a sound educational system that will benefit the recipients and the society in general, the students need to have all the basic infrastructure and conducive environment for active and purposive learning to take place. They need to be prepared not only as professionals but also as citizens who are to act intelligently and live in a democratic society. In this aspect and process of learning, students need to be acquainted with the complexity of the information that they will manage in the future. This will be impossible without capacity development for compiling, producing, applying and critically evaluating information extracted from their research activities. The process of doing this will make African education a rich and stimulating environment for learning and knowledge production.

There are set-backs in the pursuit of higher education; perhaps, the most formidable task confronting higher education is the inadequacy to articulate the relationship between the mission of the university and the specific needs of university's political, social, economic and cultural environment, and the characteristics of a rapidly globalising world. The challenges and problems confronting university education in Nigeria are multi-faceted and multi-dimensional; some of which will be examined below.

The first challenge of university education in Nigeria is the issue of globalising effect. Globalisation is a complex issue and it has become the reigning phenomenon in almost all fields of human interests and endeavours; it is the principal mirror by which different strands about human development and standards are being measured in a most meaningful manner. It is not a new concept to African societies, nay other societies in the Global South. It has its precursors in the forms of slavery, slave trade, colonialism and neo-colonialism. The importation of everything western into African continent has denied the people with any idea of sustenance because the most significant tool, which is education, has been supplanted and destroyed for the western culture to be enthroned. If education is accepted as a process of socialisation, inculturation and transmission of what is worth-while to those who are committed to it, be they children or adults; then, the implication 
of this process is one of developing knowledge ability in individuals such that one uses this knowledge to improve himself and the society. But today, schools have been potent instruments of westernisation teaching syllabi that emphasise foreign ideas, activities and values, as people emerge dazed and uprooted, despising their own culture. And if the goal of this activity is to be meaningful in the society, Nwizarh points out that the goal of education should serve the provision of the effective framework for the articulation of the appropriate public sphere of citizens who would be capable of exercising power over their political, economic and cultural lives as well as over the relevant conditions of knowledge production and acquisition (2001: 73 - 74). This is a great challenge to university education in Nigerian environment because the kind of orientation being given is unsuitable for its cultural background, its growth and development. It is not a crime to borrow from other cultures as this does not imply that one culture is superior to another since no culture is sufficient unto itself as education is a process of acculturation through which the individual is helped to attain the development of his potentialities and their maximum attention when necessary according to the right reason and to achieve thereby his perfect self-fulfillment.

The issue of funding has continuously been a source of crisis in the Nigerian educational sector. Various organisations, parents, labour unions among others have at various fora pointed the attention of government to the poor funding of the system. The effect of poor funding is evident in the brain-drain, a phenomenon that has depleted universities in Nigeria seriously. Over the past decades, due to funding and political imbroglio in the society and in "Ivory Towers" as a result of gradual exodus of many lecturers, Nigerian universities have seized to be a place for exciting search for innovation (Ogu, 2008). Some abandoned academics for other sectors of the economy, where professionals and scientists receive higher remuneration and greater social recognition, while some left the shores of the country for greener pastures where they will be appreciated and recognised. The result of this mass exodus of many experienced and young scholars fleeing from the dislocation of university life into more rewarding and challenging sectors of the society is seen today in the quality of graduates that our universities produce on yearly basis. 
Another aspect of these challenges of university education in Nigeria is in the area of using western-oriented cultural background to examine and analyse African cultural ethos, thoughts and values. Here, Owolabi (2007: 78) points out that the crisis of the university in Africa today, and ever before, is precisely that of employing a Western-oriented institution to challenge and dethrone African values. But the failure of this institution to perform its allotted assignment has to do with the ambivalence of African society itself about this foreign value system. The material benefits of western modernity have been so much enjoyed that the very quest for authenticity can not be fully effected by African universities without incurring the wrath of the ordinary people whose lives have so much been dependent on this modern culture. This ambivalence of the society about western culture is a justifiable excuse for our universities to neglect the call for cultural autonomy. For cultural autonomy may imply cultural insularity and African society can not afford to pay the price. Here, Harrison (1987: 55) avers that today, westernisation has spread into every nook and cranny in the Third World, and because of the discrimination practised against the non-westernised; it is proceeding with accelerating pace. It creeps down key arteries of indigenous society, poisoning it from within. So, the usage of western orientation in the process of developmental changes in Nigeria will continue to be a herculean task.

\section{Nigerian (African) University Education in the Twenty-first (21st) Century - The Way Forward}

In line with what had been examined from the beginning, I shall at this juncture attempt positions that must be taken in the process of re-building our educational policies toward sustaining all aspects of our society especially in Nigeria.

The first option would be a strict adherence to the provision of university autonomy using the yardstick of global best practices. Nigerian educational policies should be devoid of all these teleguided attitude of the governmental over-bearing on ivory towers. Longing for development in all areas of the society with overbearing policies of the government would demean the capabilities and abilities of the universities to contribute meaningfully to the 
development of human society. This is also in relation to the idea of decentralising the competitive structure of higher education for performance enhanced-reward system as against the executorial and over-bearing functions being carried out by National Universities Commission (NUC) especially in Nigeria, instead of advisorial functions to senates of universities.

Related to the above is the issue of funding; the issue of universities funding should be diversified by attracting private and individual sectors funding without those intended-funding agencies dictating or directing the programmes of fund allocation. Much as diversification is needed, the factor of appropriate funding by national and international development partners must form the core of higher education development in Nigeria. Funding is central to the much needed internalisation of quality in higher education and so, donor agencies must consider this a priority in the institutionalisation of global competition of higher education delivery for the development of Nigeria. Universities like Oxford, Cambridge, Harvard, Yale, and University College London among others are great today because there are endowments, foundations, individual and corporate funding toward the growth and development of their societies. This must be considered in the overall interest toward growth and development in African societies.

The value of education is limitless as there are relations between its recipients and the society in general. This is particularly in the area of inculcating critical pedagogy to educational ideologies. And it was based on this that Cajete avers that education is in crisis ... with unprecedented challenges in a global community of nations desperately struggling with massive social, economic, and cultural change (1994: 25). Towards solving the crisis above, Nwizarh proffers that critical education would assume the role of facilitating a discursive and experiential understanding of life forces in the society such that, within such a framework, it would be possible to provide, for the citizens, a critical assessment of those categories other than those erected by the official culture. In this sense, critical education involves the articulation of strategic life-models and inter-personal rapport schedules within a context animated by culturally diverse alternative view-points. 
In line with the above are the issues of indigenous education and the use of mother tongues in the dissemination of thought-patterns for individual and collective educational growth and development. For our formal education to be of any value, there is the need to recognise and admit the necessity to conform with the nature of being an African; its close links with social life both in material and spiritual senses; its collective nature; its many sidedness and its progressive development in conformity with the successive stages of physical, emotional, mental and moral development. Therefore, no one should be made a visitor to his/her own culture and the habit of not looking down on the culture, practices and emotions of the society. What the above means is that we can never adequately educate a child outside his cultural environment; all must exercise strength to develop the level of our cultural heritage, it is in itself a source of education.

Hegel declared that the individual derives his understanding and practice of virtue from the virtuous state of which he is a part while Kant's ideal community consists of men who treat one another as ends rather than means. His famous categorical imperative states that we should always act as though our individual actions were to become a universal law of nature binding on all men in secular circumstances. Therefore, the responsibility of these strata cannot be over-emphasised and waved aside in the education of the individual (Olatunji, 2001: 50). It is also in this respect that Ujomu reiterates that the fundamental task of education for national consciousness is to attempt to foster a sense of belonging and togetherness among the various peoples and interests in the Nigerian polity. Only the imbibing of core values such as honesty, industry and dedication in the discharge of duties and responsibilities can ensure the achievement of national consciousness (2001-2002: 41), as education is ultimate justification for the existence of both the individual and the society. Education should appear to be equipment for life and the ability of the individual to master and survive his environment. Here, Ehusani argues that the form of educational attainment Nigerians must have is the one that is humanistic in nature, which will call for a serious breach of our present notion and idea about development. To him, development must be a human fact. It must mean an ongoing commitment to advance from the less human conditions of 
disease, hatred, crime, war, racism, poverty, oppression, injustice, corruption, faithlessness, hopelessness to the more human conditions of health, of love, peaceful co-existence, equity, justice, community fellow-feeling, faith and hope (1997: 243); these attitudinal changes in university education would go a long way in straightening educational goals and objectives for the development of African society.

Also, on the issue of being African in our stages of life and process of reasoning, the following features of indigenous African education should be considered outstanding for human societal development, namely: its close links with social life both in material and spiritual sense; its collective nature; its many sidedness and its progressive development in conformity with the successive stages of physical, emotional, mental and moral development of her children. For our education to be of any value to each member of the society, there is the need to recognise and admit the necessity to conform to the nature of being an African. Therefore, in admitting our African values, no one should be made alien to his own society and the habit of not looking down on the culture, practice and emotions of such society should be encouraged.

\section{Conclusion}

The essence of this piece has been centred on those areas of Nigerian (African) university system that must be attended to in the best interest of all. This will be futile if we continue to theorise without making our impacts felt in the struggle for a new world order through sound and adequate education. It is clear from experiences and ground-reality that government alone cannot fund university education but that individual donors and private establishments should be beckoned upon to support the building of a virile university system. What this suggests is that all stakeholders must be ready to contribute their quota in this struggle.

It has been clearly shown that the systemic problems that affect all other sectors could be curtailed when there is a functional educational ideology from the university system. And this right educational ideology being envisaged should of course be a 
culturally- defined construct in socialising individuals to the collective culture of the whole. This, the university system must adapt because it causes change that in time creates a profound transformation of the self and the whole; this transformation is a dynamic creative process that will bring development, peace of mind, tranquility, and harmonious adaptation. This exploration of self, and relationships to inner and outer entities, requires a tearing apart to creating a new world order and a higher level of consciousness toward educational goals, objectives and sustenance in African society.

\section{References}

Arikewuyo, M. "University Management and Staff Unions in Nigeria: Issues and Challenges" SA-eDUC Journal Vol. 3, No: 1, $15-22$.

Ebijuwa, T. "Globalisation, Social Change and the Challenge of Sustainable Community Development in Nigeria" Paper presented at the Institute of Development Administration, Lagos, (2009): August 19 - 22.

Cajete, G. Look To The Mountain, An Ecology of Indigenous Education. Rio Rancho: Kivaki Press, 1994.

Egbokhare, F. "University Decline and Its Reasons: Imperatives for Change and Relevance" in Joseph Kenny. (Ed.) "Cultural Heritage and Contemporary Change". Nigerian Philosophical Studies, II. Series II, Vol. II, (2007): 58 - 68.

Ehusani, G. An Afro-Christian Vision "OZOVEHE!" Toward A More Humanised World. Maryland: University Press of America, 1991.

Harison, P. Inside The Third World. Middlesex: Penguin Books Ltd, 1987.

Kenny, J. "The Lessons of World History of the University for Nigeria Today in Kenny, J. (Ed.) "Cultural Heritage and Contemporary Change" Nigerian Philosophical Studies, II. Series II, Vol. II (2007): 19 - 29.

Nwizarh, J. "Education and Politics in Africa: The Imperative of Critical Pedagogy" in Ogunmodede, F. (Ed.) West African Journal of Philosophical Studies Vol. 4 (Dec. 2001): 72 - 85. 
Ogu, E. "Challenges Facing Nigerian Universities" in Nigeria World (Accessed on January 12, 2010) http://nigeriaworld.com/articles/ 2008/sep/300.html.

Ogunmodede, F. Obafemi Awolowo's Socio-Political Philosophy. An Unpublished Ph.D thesis submitted to Pontifical Urbaniana University, Faculty of Philosophy, Rome, Italy : 1986.

Olatunji, F. Character-Building in Yoruba Educational Ideology: A Philosophical Appraisal. An unpublished project submitted to the Department of Philosophy, Catholic Seminary of Ss. Peter and Paul, Ibadan, Nigeria: 2001.

Owolabi, K. "Knowledge Production, Cultural Identity and Globalisation: African Universities and the Challenges of Authenticity and Transformation in the Twenty-first Century" in Kenny, J. (Ed.) "Cultural Heritage and Contemporary Change: The Idea of an African University" Nigerian Philosophical Studies, II. Series II Vol. II (2007): 71 - 84.

Ujomu, P. "Education and National Consciousness in an African Nation-State: Problems and Prospects" The Sage Magazine: A Philosophical and General Interest Magazine. Vol. 14 (June 2001 June 2002): 40 - 41 . 